\title{
POLA KUMAN DAN UJI SENSITIVITAS TERHADAP ANTIBIOTIK PADA INFEKSI PLEURA DI RSUP. Dr. M. DJAMIL PADANG
}

Mulya Eltario ${ }^{1}$ Lillah $^{2}$, Tuty Prihandani²

\begin{abstract}
Abstrak
Infeksi pleura merupakan salah satu penyebab terbanyak morbiditas dan mortalitas dengan insidens terus meningkat pada dewasa. Terapi pasien secara empiris dengan antibiotik berspektrum luas dan polifarmasi sering tidak bermanfaat. Mikroba penyebab infeksi pleura bergeser secara perlahan dari positif Gram menjadi negatif Gram sejak antibiotik semakin banyak digunakan. Penelitian ini bertujuan untuk mengetahui pola kuman dan uji sensitivitas terhadap antibiotik pada infeksi pleura di RSUP Dr. M. Djamil Padang. Penelitian deskriptif dilakukan pada 55 spesimen cairan pleura dari bangsal paru dan penyakit dalam yang dikultur menggunakan agar darah di Laboratorium Sentral RSUP Dr. M. Djamil Padang periode Januari 2015-Desember 2015. Identifikasi bakteri dengan pewarnaan Gram dan tes biokimia. Uji sensitivitas antibiotik menggunakan metode Kirby-Bauer sesuai dengan standar CLSI. Bakteri yang ditemukan pada spesimen cairan pleura adalah Klebsiella sp 21(38\%), Staphylococcus sp (25\%), Pseudomonas sp (22\%), Proteus sp (5\%), Streptococcus sp (5\%), Acinetobacter sp (3,6\%). Klebsiella sp sensitif terhadap Meropenem (95,2\%), resisten terhadap Ampicilin (90,5\%). Staphylococcus sp sensitif terhadap Meropenem (100\%), resisten terhadap Ampicilin (57,1\%). Pseudomonas sp sensitif terhadap Meropenem (75\%), resisten terhadap Ampicilin (100\%). Proteus sp sensitif terhadap Meropenem (66,7\%), resisten terhadap Ampicilin (100\%). Streptococcus sp sensitif terhadap Cefoperazone (100\%), resisten terhadap Cefotaxime (100\%). Acinetobacter sp sensitif terhadap Chloramphenicol (100\%), resisten terhadap Cefotaxime (100\%). Bakteri terbanyak penyebab infeksi pleura di bangsal paru dan penyakit dalam periode Januari 2015 sampai Desember 2015 adalah Klebsiella sp, yang sensitif terhadap Meropenem dan resisten terhadap Ampicilin. Pelaporan perlu dilakukan secara berkala sebagai pedoman dalam memberikan antibiotik yang tepat.
\end{abstract}

Kata kunci: Infeksi Pleura, Pola Kuman, Uji Sensitivitas Antibiotik.

\begin{abstract}
Pleural infection is one of major cause of morbidity and mortality, and the incidence continues rising in adults. The patients are treated with empirical antibiotics that cover the spectrum of likely pathogens, resulting in polypharmacy and its associated disadvantages. The microbial etiology of pleural space infections has changed since the introduction of antibiotics. Gram positive organisms are slowly and steadily losing their foothold in the pleural space to the more resilient and resistant Gram negative bacterias. The aim of this study was to determine the pattern of bacteria and antibiotics sensitivity test of pleural infection in Dr.M.Djamil Hospital, Padang. This was a descriptive study of 55 pleural fluid specimens from pulmonology and internal wards in Central Laboratory Dr. M. Djamil Hospital Padang from January 2015 - December 2015. The specimens were cultured in blood agar. Bacterias were identified by Gram staining and biochemical tests. Antibiotics sensitivity test were performed using Kirby-Bauer method according to CLSI standard. The common bacteria founded in pleural infection specimens was Klebsiella sp (38\%), Staphylococcus sp (25\%), Pseudomonas sp (22\%), Proteus sp(5\%), Streptococcus sp (5\%), Acinetobacter sp (3,6\%). Klebsiella sp sensitive to Meropenem (95,2\%), resistant to Ampicilin (90,5\%). Staphylococcus sp sensitive to Meropenem (100\%), resistant to Ampicilin (57,1\%). Pseudomonas sp sensitive to Meropenem (75\%), resistant to Ampicilin (100\%). Proteus sp sensitive to Meropenem (66,7\%), resistant to Ampicilin (100\%). Streptococcus sp sensitive to Cefoperazone (100\%), resistant to Cefotaxime (100\%). Acinetobacter sp sensitive to Chloramphenicol (100\%), resistant to Cefotaxime (100\%). The most common bacteria in pleural infection from pulmonology and internal wards from January 2015 until December 2015 is Klebsiella sp, sensitive to Meropenem and resistant to Ampicilin. Reporting should be done periodically as a guide in providing the appropriate antibiotics.
\end{abstract}

Keywords: Pleural Infection, Pattern of Bacteria, Antibiotics Susceptibility Test.

Affiliasi penulis :1.PPDS Patologi Klinik Fakultas Kedokteran Universitas Andalas. 2. Bagian Patologi Klinik Fakultas Kedokteran Universitas Andalas / RSUP Dr. M. Djamil, Padang

Korespondensi : Mulya Eltario e- mail: sir_ryo007@yahoo.com Telp/HP: 085263740007

\section{PENDAHULUAN}

Infeksi pleura merupakan salah satu penyebab terbanyak morbiditas dan mortalitas dengan insidens terus meningkat pada dewasa. Penyakit ini dilaporkan $30 \%$ ditemukan pada semua kasus infeksi dewasa. Terapi pasien secara empiris dengan antibiotik berspektrum luas dan polifarmasi sering tidak bermanfaat. Mikroba penyebab infeksi pleura bergeser secara perlahan dari positif Gram menjadi negatif Gram sejak antibiotik semakin banyak digunakan. Mortalitas meningkat $40 \%$ pada mikroba negatif Gram sehingga identifikasi bakteri dengan segera sangat dibutuhkan untuk terapi yang adekuat. ${ }^{1,2}$

Faktor risiko infeksi pleura sama dengan pneumonia, meskipun terdapat beberapa kondisi lain untuk berkembang menjadi empiema termasuk diabetes melitus, penggunaan kortikosteroid sebagai terapi imunosupresan, refluks gastroesofagus, alkoholism dan penyalahgunaan obat intravena. Riwayat aspirasi dan kebersihan mulut yang kurang 
baik sering menimbulkan infeksi bakteri anaerob. Infeksi pleura iatrogenik sebagian besar disebabkan oleh intervensi pada pleura dan toraks atau operasi pada esofagus dan beberapa kasus faktor risiko tidak diketahui. $^{2}$

Insidens infeksi pleura dilaporkan meningkat di seluruh dunia. Penelitian pada tahun 1995-2003 ditemukan bahwa infeksi pleura meningkat 2,2\% dari 11294 pasien yang diteliti pada seluruh rumah sakit di Canada. $^{3}$ Penelitian tahun 1987-2004 ditemukan bahwa infeksi pleura meningkat $2,8 \%$ tiap tahun dari 4424 pasien yang diteliti di seluruh rumah sakit Amerika Serikat. ${ }^{4}$ Penelitian yang dilakukan antara tahun 1996-2009 ditemukan infeksi pleura meningkat sebesar $7,6 \%-14,9 \%$ di seluruh rumah sakit Spanyol. ${ }^{5}$ Angka kejadian infeksi pleura tahun 1997-2011 meningkat sebesar $2,5-3,5 \%$ tiap tahun di seluruh rumah sakit Denmark. ${ }^{6}$

Mikroorganisme penyebab infeksi pleura yang paling sering ditemukan adalah Pseudomonas aeruginosa, Enterobactriaceae, Klebsiella spp, Escherichia coli, Enterobacter cloacae, Proteus mirabilis, Staphylococcus aureus, Acinetobacter baumanni, Streptococcus pneumonia, Candida spp,.7,8 Penelitian pada tahun 1989-1998 di National Taiwan University Hospital menemukan penyebab terbanyak infeksi pleura adalah Klebsiella spp (24,4\%). ${ }^{9}$ Penelitian yang dilakukan oleh Oxford University mendapatkan mikroorganisme terbanyak adalah Staphylococcus aureus (25\%), Enterobacteriaceae (33,4\%), Enterococci 12\%, Pseudomonas spp (5\%). ${ }^{10}$ Penelitian yang dilakukan di Inggris menemukan penyebab terbanyak infeksi pleura adalah Streptococcus spp (5\%), Streptococcus anginosus (4\%). ${ }^{1}$ Penelitian yang dilakukan antara tahun 2004 2005 di rumah sakit Inggris didapatkan mikroorganisme penyebab terbanyak adalah Streptococcus spp (52\%), Staphylococcus aureus (20\%), (Fusobacterium spp, Bacteroides spp, Peptostreptococcus spp) (20\%), (Escherichia coli, Pseudomonas aeruginosa, Klebsiella spp) $(17 \%)^{2}$ Penelitian yang dilakukan di India menemukan penyebab infeksi pleura terbanyak adalah Pseudomonas aeruginosa (55,2\%), Enterobacteriaceae (33,4\%), Klebsiella spp $(21,8 \%){ }^{8}$

Penelitian terhadap kejadian infeksi pleura di RS. Dr. Wahidin Sudirohusodo Makassar sejak Januari 2004 sampai Desember 2005 menemukan bakteri terbanyak adalah Acinetobacter calcoaceticus (33,3\%), Staphylococcus epidermidis (22,2\%), Pseudomonas aeruginosa (11,1\%), dan Enterobacter hafniae $(11,1 \%) .{ }^{11}$ Penelitian retrospektif yang dilakukan di RSUD Dr. Moewardi Surakarta antara Januari 2009-November 2011 menemukan bakteri terbanyak adalah Pseudomonas aeruginosa (15,2\%), Enterobacter cloacae $(6,1 \%)$, Klebsiella pneumoniae (3\%), Acinetobacter spp (3\%), dan Serratia marcessens (3\%) dan sensitif terhadap meropenem, imipenem, amikasin, pipperacillin, ertapenem, colistin, levofloksasin. ${ }^{12}$
Pelaporan pola kuman dan uji sensitivitas sangat penting dilakukan secara berkala setiap tahun terutama terhadap pasien di bangsal paru dan penyakit dalam sebagai pedoman klinisi dalam memberikan antibiotik yang tepat dan mencegah penyebaran infeksi lebih lanjut. RSUP. Dr. M. Djamil Padang sebagai pusat rujukan nasional sebaiknya memiliki data mengenai pola kuman dan uji sensitivitas terhadap antibiotik pasien infeksi pleura yang diperbaharui setiap tahun dan diinformasikan kepada klinisi di bangsal paru dan penyakit dalam. Pemakaian obat antibiotik berspektrum luas serta lama masa rawatan pasien di bangsal paru dan penyakit dalam RSUP. Dr. M. Djamil Padang menjadi dasar ketertarikan peneliti untuk mengetahui pola kuman dan mengetahui bagaimana hasil uji sensitivitas antibiotik kuman tersebut di bangsal paru dan penyakit dalam RSUP. Dr. M. Djamil Padang periode Januari-Desember 2015. Tujuan penelitian ini adalah untuk mengetahui pola kuman dan uji sensitivitas antibiotik infeksi pleura di bangsal paru dan penyakit dalam RSUP. Dr. M. Djamil Padang.

Tujuan penelitian ini adalah untuk mengetahui pola kuman dan uji sensitivitas antibiotik infeksi pleura di bangsal paru dan penyakit dalam RSUP. Dr. M. Djamil Padang.

\section{METODE}

Penelitian ini adalah penelitian deskriptif yang dilakukan di Laboratorium Sentral RSUP. Dr. M. Djamil Padang dari Januari sampai Desember 2015. Subyek penelitian adalah kultur positif dari spesimen cairan pleura yang menderita infeksi pleura selama periode Januari sampai Desember 2015.

\section{HASIL}

Telah dilakukan penelitian terhadap 55 spesimen cairan pleura dari pasien infeksi pleura yang dirawat di bangsal paru dan penyakit dalam periode Januari - Desember 2015. Bakteri yang ditemukan adalah Klebsiella sp 38\%, Staphylococcus sp 25\%, Pseudomonas sp 22\%, Proteus sp 5\%, Streptococcus sp 5\%, Acinetobacter sp 3,6\% (Gambar 1).

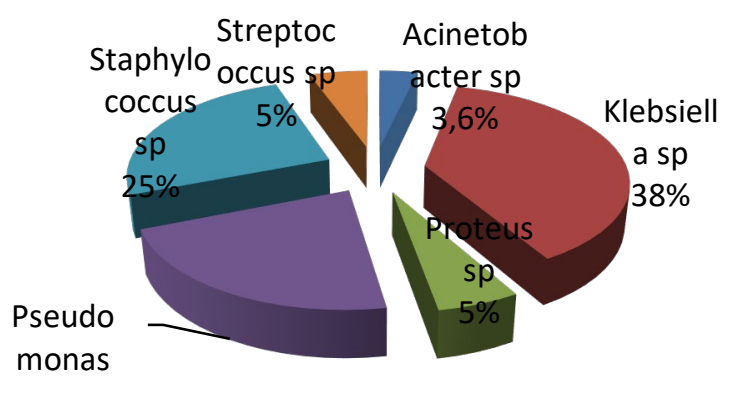

sp

Gambar 1. Hasil Kultur Cairan Pleura Pasien Infeksi Pleura yang dirawat di Bangsal Paru dan Penyakit Dalam RSUP Dr. M. Djamil Padang Periode Januari Desember 2015 
Hasil uji sensitivitas terhadap Klebsiella $s p$ pada spesimen cairan pleura pasien infeksi pleura yang dirawat di bangsal paru dan penyakit dalam periode Januari - Desember 2015 didapatkan bahwa kuman ini sebagian besar resisten terhadap antibiotik yang diuji, tetapi beberapa masih sensitif terhadap Meropenem (95,2\%), Chloramphenicol (61,9\%), Ciprofloxacin (57,1\%), Fosfomicin (57,1\%) dan Levofloxacin $(57,1 \%)$. Resistensi kuman Klebsiella $s p$ didapatkan tertinggi terhadap Ampicilin (90,5\%), Erithromicin (71,4\%), Ceftriaxone (66,7\%), Cefoperazone (61,9\%) dan Cefotaxime (61,9\%) (Gambar 2).

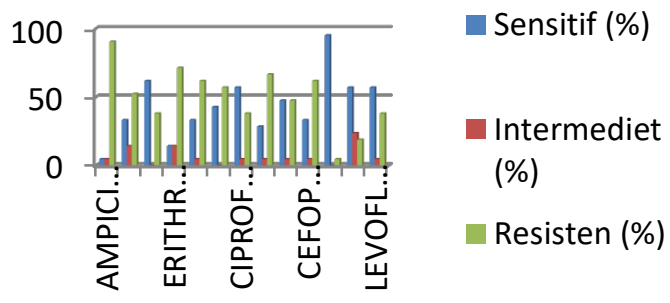

Gambar 2. Hasil Uji Sensitivitas Klebsiella sp terhadap Beberapa Antibiotik Periode Januari - Desember 2015

Hasil uji sensitivitas terhadap Stapylococcus $s p$ pada spesimen cairan pleura pasien infeksi pleura yang dirawat di bangsal paru dan penyakit dalam periode Januari - Desember 2015 didapatkan bahwa kuman ini sensitif terhadap Meropenem (100\%), Cefoperazone (71,4\%), Amoxillin (64,3\%), Chloramphenicol (64,3\%), Gentamycin. Resistensi kuman Staphylococcus $s p$ didapatkan tertinggi terhadap Ampicilin (57,1\%), Erithromicin (50\%) (Gambar 3).

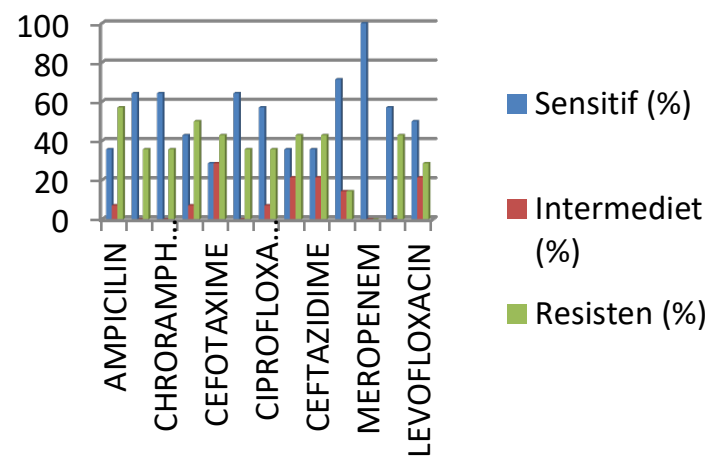

Gambar 3. Hasil Uji Sensitivitas Stapylococcus $s p$ terhadap Beberapa Antibiotik Periode Januari Desember 2015

Hasil uji sensitivitas terhadap Pseudomonas $s p$ pada spesimen cairan pleura pasien infeksi pleura yang dirawat di bangsal paru dan penyakit dalam periode Januari - Desember 2015 didapatkan bahwa kuman ini sensitif terhadap Meropenem (75\%), Ciprofloxacin (75\%), Levofloxacin (66,7\%). Resistensi kuman Pseudomonas sp didapatkan tertinggi terhadap Ampicilin (100\%), Erithromicin (100\%), Amoxillin (83,3\%), Chloramphenicol (83,3\%) (Gambar 4).

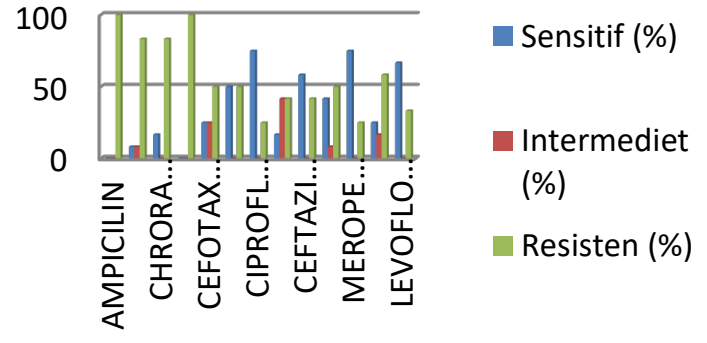

Gambar 4. Hasil Uji Sensitivitas Pseudomonas $s p$ terhadap Beberapa Antibiotik Periode Januari Desember 2015

Hasil uji sensitivitas terhadap Proteus sp pada spesimen cairan pleura pasien infeksi pleura yang dirawat di bangsal paru dan penyakit dalam periode Januari - Desember 2015 didapatkan bahwa kuman ini sensitif terhadap Meropenem (66,7\%), Ceftazidime (66,7\%), Amoxillin (66,7\%), Levofloxacin (66,7\%). Resistensi kuman Proteus sp didapatkan tertinggi terhadap Ampicilin (100\%), Erithromicin (100\%), Cefotaxime (100\%) (Gambar 5).

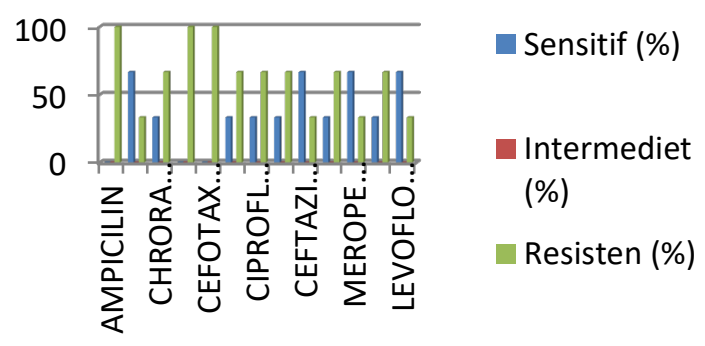

Gambar 5. Hasil Uji Sensitivitas Proteus sp terhadap Beberapa Antibiotik Periode Januari - Desember 2015

Hasil uji sensitivitas terhadap Streptococcus $s p$ pada spesimen cairan pleura pasien infeksi pleura yang dirawat di bangsal paru dan penyakit dalam periode Januari - Desember 2015 didapatkan bahwa kuman ini sensitif terhadap Cefoperazone (100\%), Fosfomicin (100\%), Meropenem (66,7\%), Amoxillin $(66,7 \%)$, Levofloxacin (66,7\%), Gentamicin (66,7\%), Ciprofloxacin (66,7\%), Amoxillin (66,7\%). Resistensi kuman Streptococcus sp didapatkan tertinggi terhadap Cefotaxime (100\%), Ceftazidime (100\%), Ampicilin $(66,7 \%)$, Erithromicin $(66,7 \%)$, Ceftriaxone $(66,7 \%)$ (Gambar 6). 


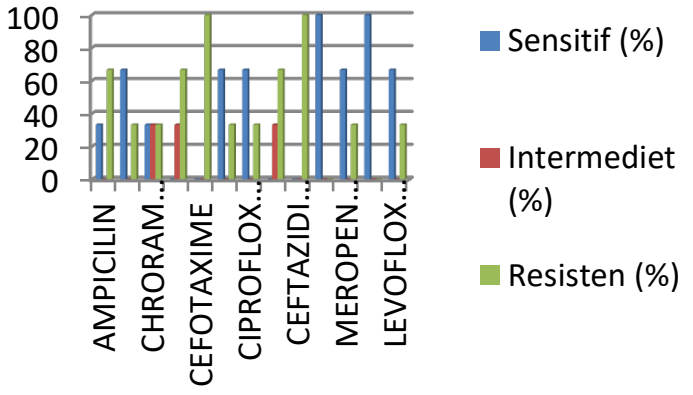

Gambar 6. Hasil Uji Sensitivitas Streptococcus $s p$ terhadap Beberapa Antibiotik Periode Januari Desember 2015

Hasil uji sensitivitas terhadap Acinetobacter $s p$ pada spesimen cairan pleura pasien infeksi pleura yang dirawat di bangsal paru dan penyakit dalam periode Januari - Desember 2015 didapatkan hanya ditemukan 2 kasus dan sensitif terhadap Chloramphenicol (100\%). Resistensi kuman Acinetobacter sp didapatkan resisten mencapai $100 \%$ terhadap Cefotaxime, Ceftazidime, Ampicilin, Ciprofloxacin, Erithromicin, Ceftriaxone, Cefoperazone, Levofloxacin (Gambar7).

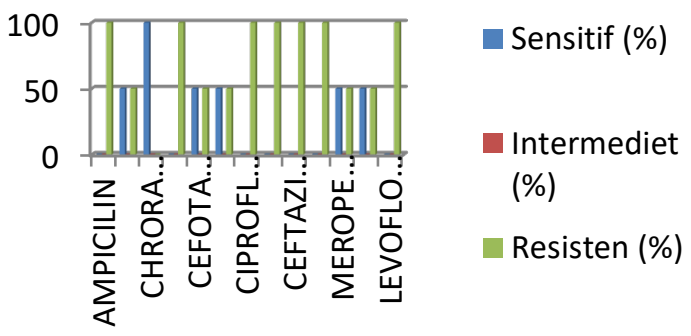

Gambar 7. Hasil Uji Sensitivitas Acinetobacter $s p$ terhadap Beberapa Antibiotika Periode Januari Desember 2015

\section{PEMBAHASAN}

Bakteri penyebab infeksi cairan pleura di bangsal paru dan penyakit dalam periode Januari Desember 2015 adalah Klebsiella sp. Bakteri lain yang ditemukan adalah Staphylococcus sp, Pseudomonas $s p$, Proteus sp, Streptococcus sp, Acinetobacter sp. Beberapa penelitian menemukan Streptococcus $s p$ sebagai penyebab terbanyak infeksi cairan pleura, seperti yang dilakukan pada tahun 2004-2005 di rumah sakit Inggris. ${ }^{2}$ Hasil penelitian tersebut sesuai dengan penelitian pada tahun 1989-1998 di National Taiwan University Hospital menemukan penyebab terbanyak infeksi pleura adalah Klebsiella spp $(24,4 \%) .^{9}$

Hasil uji sensitivitas terhadap Klebsiella $s p$ pada spesimen cairan pleura pasien infeksi pleura yang dirawat di bangsal paru dan penyakit dalam periode Januari-Desember 2015 didapatkan bahwa kuman ini sebagian besar resisten terhadap antibiotik yang diuji, tetapi beberapa masih sensitif terhadap Meropenem (95,2\%), Chloramphenicol (61,9\%), Ciprofloxacin $(57,1 \%)$, Fosfomicin $(57,1 \%)$ dan
Levofloxacin $(57,1 \%)$. Resistensi kuman Klebsiella $s p$ didapatkan tertinggi terhadap Ampicilin (90,5\%), Erithromicin (71,4\%), Ceftriaxone (66,7\%), Cefoperazone $(61,9 \%)$ dan Cefotaxime $(61,9 \%)$

Resistensi terhadap antibiotik kemungkinan disebabkan oleh terapi pasien secara empiris dengan antibiotik berspektrum luas dan polifarmasi yang sering tidak bermanfaat. Mikroba penyebab infeksi pleura bergeser secara perlahan dari positif Gram menjadi negatif Gram sejak antibiotik semakin banyak digunakan. Mortalitas meningkat $40 \%$ pada mikroba negatif Gram sehingga identifikasi bakteri dengan segera sangat dibutuhkan untuk terapi yang adekuat. ${ }^{1,2}$

\section{SIMPULAN}

Bakteri terbanyak yang ditemukan pada pasien infeksi cairan pleura di bangsal paru dan penyakit dalam pada periode Januari-Desember 2015 adalah Klebsiella $s p$ yang sensitif terhadap Meropenem dan resisten terhadap Ampicilin, Erithromicin, Ceftriaxone, Cefoperazone dan Cefotaxime. Pelaporan pola kuman dan uji sensitivitas perlu dilakukan secara berkala sebagai pedoman klinisi dalam memberikan antibiotik yang tepat dan mencegah penyebaran infeksi lebih lanjut.

\section{DAFTAR PUSTAKA}

1. Menzies SM, Rahman NM, Wrightsan JM, Blood Culture Bottle of Pleural Fluid in Pleural Infection, Journal of Respiratory Infection. 2011; 66:658662

2. Davies EH, Davies Robert JO, Davies Christopher WH, Management of pleural infection in adults: British Thoracic Society pleural disease guideline: Thorax 2010; 65(Suppl 2):ii41-ii53

3. Finley C, Clifton J, FitzGerald JM, Yee J, Empyema: An increasing concern in Canada; in Canada Respiratory Journal: 2008: 15(2):85-9.

4. Farjah F, Symons RG, Krishnadasan B, Wood $D E$, Flum DR, Management of pleural space infections: A population-based analysis 2006; Journal Thorac Cardiovascular Surgery. 2007. 133:346-51

5. Burgos J, Lujan M, Falco V, Sanchez A, Puig M, Borrego A, Fontanals D, Planes AM, Pahissa A, Rello J. The Spectrum of Pneumococcal Empyema in Adults in Early 21st Century Clinical Infectious Diseases. 2011; 53(3):254-61.

6. Søgaard $M$, Nielsen RB, Nørgaard M, Kornum JB, Schønheyder HC, Thomsen RW. Incidence, Length of Stay, and Prognosis of Hospitalized Patients With Pleural Empyema A 15-Year Danish Nationwide Cohort Study: Chest Journal. 2014; 145:189-192.

7. Lisboa T, Waterer GW, Lee GYC, Pleural infection: Changing bacteriology and its implications: Asian Pacific Society of Respirology Journal. 2011; 16:598-603. 
8. Sonali J, JN Banavaliker, EMPYEMA THORACIS: Bacteriological analysis of pleural fluid from the largest chest hospital in Delhi 2013, in IOSR Journal of Dental and Medical Sciences (IOSR-JDMS): Vol 3: Issue 6: PP 46-51

9. Chen KY, Hsueh PR, Liaw YS, Yang PC, Luh KT. A, 10-year experience with bacteriology of acute thoracic empyema: Emphasis on klebsiella pneumonia in patients with diabetes melitus 2000. Chest. 2000; 117:1685-9.

10. Maskell NA, Batt S, Hedley EL, Davies CW, Gillespie SH, Davies RJ, The Bacteriology of Pleural Infection by Genetics and Standard Methods and its Mortality Signifiance, American Journal Respiration Critical Care Medicine: 2006; 174:817-23.

11. Ibrahim N, Windarwati, Hardjoeno. Pola dan Sensitivitas Kuman Terhadap Antimikroba Pada Berbagai Cairan Tubuh di RSUP Wahidin Sudirohusodo Makassar, dalam Kumpulan Penyakit Infeksi \& Tes Kultur Sensitivitas Kuman serta Upaya Pengendaliannya. Makasar: Lembaga Penerbitan Universitas Hasanuddin; 2007. P336-42.

12. Surjanto E, Sutanto YS, Harsini, Puspitasari $Y$, Karakteristik Pasien Empiema di Rumah Sakit Dr. Moewardi. J Respir Indo. 2013; 33:117-21. 